\title{
THE PLACE OF LIABILITY IN RESPECT TO THE FREEDOM OF EXPRESSION
}

\author{
V. Chiper (Mihalcea)*
}

\author{
Valentina Chiper (Mihalcea) \\ Faculty of Law and Administrative Sciences \\ University of Craiova, Craiova, Romania \\ *Correspondence: Valentina Chiper (Mihalcea), University of Craiova, \\ 13 Al. I. Cuza Street, Craiova, 200585, Dolj, Romania \\ E-mail: av_mihalcea@yahoo.com
}

\begin{abstract}
The terms 'freedom' and 'liability' are polysemantic and bear multi-valent meanings according to the field.

Civil or criminal liability, through the interdictions it brings, sets the border between the legal or illegal discourse. The guilt defined by criminal and civil crimes transfers a set of obligations to the communicator ${ }^{1}$. Terms like 'excess' or 'abuse' of the freedom of expression is another way to define it.

We shall try hereinafter to answer the question whether it is better to regulate and engage the civil liability or criminal liability in relation to the freedom of expression.
\end{abstract}

Keywords: freedom of expression, civil liability, criminal liability

\section{Introduction}

Freedom of expression has been considered from the ancient times as a powerful weapon and sometimes as a menace to power, whether religious or political, social or economic. The most powerful legal vehicle in ensuring the control over works is censure, gradually replaced by liability.

The freedom of expression, one of the oldest liberties of the citizen and known either under this title or as the freedom of the word or press essentially include two freedoms: the freedom of expression supposes the liberty to search for, to receive and to disseminate information and ideas of any kind, in verbal, written, printed or artistic format and irrespectively of the frontiers or any other means at its discretion ${ }^{2}$, without any interference of public bodies and across any border ${ }^{3}$.

The terms 'freedom' and 'liability' are polysemantic and bear multi-valent meanings according to the field - political, legal or symbolic. The concept of 'freedom' known two major approached in the reference literature. The first is a natural approach according to each every person is presumed to have innate wisdom to "rule, to be born with the equal and imprescriptible right to live independently of his/her neighbours and to behave according to his/her understanding of destiny" "so that the judiciary freedom is characterized by an area

\footnotetext{
* Acknowledgements: This work was supported by the strategic grant POSDRU/CPP107/DMI1.5/S/78421, Project ID 78421 (2010), co-financed by the European Social Fund - Investing in People, within the Sectorial Operational Programme Human Resources Development 2007 - 2013, University of Craiova, Faculty of Law and Administrative Sciences.

${ }^{1}$ P. Jourdain, Les principes de la responsabilité civile, Dalloz, Paris, 2000, 5th édition, p. 48.

${ }^{2}$ Art. 19 of the International Pact on civil and political rights, adopted by UN General Assembly on December $16,1966$.

${ }^{3}$ Art. 10 of the Convention for the Protection of Human Rights and Fundamental Freedoms.

${ }^{4}$ Tocquevile, État social et politique de la France avant et depuis 1799, 1838, renewed edition by GarnierFlammarion, 1988, p. 80.
} 
of self-determination granted to a person in a space of opportunities beyond which law no longer authorizes. The second approach of freedom consists in understanding freedom in terms of the protection granted to him/her by right by the existence of a judiciary guarantee of individual independence.

The link between the freedom of expression and democracy relies on the "the ideological ratio of legitimacy", The rule of law supposes knowing the constitutional right to freedom of expression. Moreover, the constitutionalization of the freedom of expression in democracy raises the question of its link to other freedoms, especially to the conciliation of the freedom of expression with someone else's right.

Judicial liability has been appreciated as "the intromission in the exercise of the freedom of expression to the extent that expressing or not expressing something binds the author to be held liable by exposure to punishment" ". Judiciary liability may be classified as a response whereby the responsible person must turn to account before a third party for a fact, behaviour or situation before the courts and assume consequences ${ }^{7}$.

Therefore, in the private law, liability is of two types: criminal or civil. In respect to the freedom of expression, criminal liability consists in being liable for the prejudice caused to society, subject to a punishment of criminal nature. Civil liability is the obligation to respond for an individual damage which entails the obligation to compensate prejudicing consequences.

Civil or criminal liability, through the interdictions it brings, sets the border between the legal or illegal discourse. The guilt defined by criminal and civil crimes transfers a set of obligations to the communicator ${ }^{8}$. Terms like 'excess' or 'abuse' of the freedom of expression is another way to define it.

We shall try hereinafter to answer the question whether it is better to regulate and engage the civil liability or criminal liability in relation to the freedom of expression.

\section{The place of criminal liability in respect to the freedom of expression}

Article 30, paragraph 8 of the Romanian Constitution, the final thesis, states that "indictable offences of the press shall be established by law". Erroneously, the Constitutional Court, by Decision no. 62 of January 18, 2007, reviewing the unconstitutionality of the text cancelling contempt and outrage specified in Articles 206 and of the Criminal Code, grounds its settlement on the lack of the press law and on the need to include offences of the press in the law.

The disposition under article 30, paragraph 8 is a repressive and shall therefore be construed senso strictum, in the sense that "potential offences of the press can only be established by law and not by an administrative fiscal regulation specifically in order to better protect the freedom of expression against the authoritarian tendencies of the executive or judiciary power and not to restrict it. This does not mean that the law must necessarily stipulate the offences of the press" "9.

The cancelled dispositions can no longer be re-enacted upon the unconstitutional declaration of the regulation cancelling such dispositions without the Parliament or, as appropriate, the Government adopting a new regulation addressing the concerned area. The same was recently stated by the High Court of Cassation and Justice by Decision no. 8 of October 18, 2010 upon the admission of the appeal in the interest of the law lodged by the Romania's Attorney General in respect to the impact of Decision no. 62/2007.

\footnotetext{
${ }^{5}$ Louriane Josende, Liberté d'expression et démocratie. Réflexion sur un paradoxe, Bruylant, Brussels, 2010, p. 247.

${ }^{6}$ Guillaume Lécuyer, Liberté d'expression et responsabilité. Étude de droit privé. Thèse, Dalloz, Paris, 2006, p. 17.

${ }^{7}$ Geneviève Viney, La responsabilité, APD, 1977, p. 278.

${ }^{8}$ V. Jourdain, Les principes de la responsabilité civile, Dalloz, Paris, 2000, 5th edition, p. 48.

9 D. C. Dănişor, S. Rădulețu, Competența Curții Constituționale. Insulta. Calomnia. Controlul normelor de abrogare, in "Curierul Judiciar” Journal, no. 3/2007, Bucharest, C.H. Beck Publishing House, 2007.
} 
Offences of the press aim at punishing the excesses of expression in the media. However, article 205-206 of the Criminal Code not only considers the specific nature of offences of the press, but also their review-widened framework in terms of securing the freedom of expression, constantly supported by the ECHR case law since it deals with mass information, due to their specific operating conditions and their function in the democratic society and to the fact that it affects the principle of the presumption of innocence through the reversal of the burden of proof and the impossibility of the proof of veracity, sometimes a true probation diabolica, which finally represents a powerful restriction of the press freedom and a violation of article 10 of the Convention, subject to the risk of such freedom transforming from principle to exception.

As the European Court assessed and guided in many occasions, a careful distinction must be made between facts and judgments of value. If the materiality of the facts can be proven, the accuracy of the latter is not feasible for demonstration.

The relationship between the criminal law and the human rights is subject to a paradox since the criminal law embodies both the protection and the menace to fundamental rights and freedoms ${ }^{10}$, or, as Ch. Van den Wijngaert said it in metaphorical words in 1995 in a speech on the issue of the European citizen face to the criminal justice in the EU, human rights are both the "shield" and the "sword" in criminal law.

In a first approach, the criminal law is a law of strictest necessity. It "must not intervene unless all other judiciary approaches prove to be insufficient" "11. In another approach, from the victim's standpoint, the intention to harm in the criminal trial seems to be more powerful than in the civil trial of impersonal, abstract nature ${ }^{12}$.

The UN's Council for Human Rights and the Council of Europe are against the use of the criminal law in the media. In addition, most European states appeal to civil liability only. France is the country beating the record of criminal offences of the press, also due to the preservation of the Press Law of July $29,1881^{13}$.

The Resolution no. 1577 of October 4, 2007, passed by the Parliamentary Assembly of the Council of Europe, recalls the hostility of the ECHR case law to criminal sanctions. It must be understood however that in principle, the European Court does not sanction the use of the criminal law in respect to the press since it considers that the dominant position of governments asking it to state its reserves to the use of criminal punishment, especially when there are other means to hold someone liable for unreasonable attacks and criticism ${ }^{14}$. Nevertheless ${ }^{15}$, the same reserve shall not apply in situations when criminal pursuit is initiated by an individual.

The punishment in terms of proportionality is justified when there is no other way to protect the right secured by the Convention. The European Court appeals to the subsidiarity of the use of criminal law resulting in the use of other mechanisms to protect the rights of persons, other than the criminal provisions ${ }^{16}$.

There is a constant disappearance of coercive laws in relation to the press at the level of the European Court. Mass information means are not the forth state power since this would turn the media in a "mediocracy" ("powers or counter-powers"). Although it does not

\footnotetext{
${ }^{10}$ Mireille Delmas-Marty, Le paradoxe pénal, in Libertés et droit fundamentaux, coordinated by M. DelmasMarty and Lucas de Leyssac, Paris, Seuil, 1996, p. 368.

${ }^{11}$ Renée Koering-Joulin, Jean- François Seuvic, Droits fondamentaux et droit criminel, AJDA spécial, $1998, \mathrm{p}$. 106.

12 Bouloc Bernard, Vers un déclin de la sanction pénal des atteintes a la dignite?, Recueil Dalloz Sirey, 21/05/2009, n²0, p. 1373.

${ }^{13}$ Gérard Spitéri, Le journaliste et ses pouvoirs, PUF, coll. "Essais", 2004, p. 202.

${ }^{14}$ ECHR, March 4, 2003, Yasar Kemel versus Turkey, § 33, (http://www.echr.coe.int/).

${ }^{15}$ ECHR, October 22, 2007, Lindon Otchakovsky-Laurrens et al versus France, §59; ECHR, January 24, 2008, Coutant versus France, in Revue de science criminelle et de droit comparé, 2008, p. 706, obs. Marguénaud.

${ }^{16}$ ECHR, October 3, 2000, Du Roy and Malaurie versus France, §36.
} 
represent the public opinion, it "has not the specialized knowledge of institutions" and is not subject to the democratic control ${ }^{17}$.

"The punishment by imprisonment for an offence perpetrated in the press may only be consistent with the freedom of expression in extraordinary circumstances, especially when other fundamental rights have been severely prejudiced, for instance if a hatred or violencestirring discourse is made available to the public" $"$.

The European Court broadened the concept of criminal matter by including sanctions classified as disciplinary or administrative in the domestic laws of the states according to the seriousness ${ }^{19}$ of the acts, because they have both a repressive and dissuasive nature in the same time. The Court in Strasbourg shows that "three criteria determine the existence of a 'charge in criminal matter': the judiciary qualification as offence in the domestic law, the very nature of such office and the nature and gravity of the punishment" ${ }^{20}$."In our law, the criminal matter is regulated separately from the delinquency matter. The two types of sanctions are nevertheless conceived in terms of continuity of purposefulness, the delinquency law defending the social values not protected by the criminal law"21.

Although the authority of inflicting punishments belongs in principle to national jurisdictions, the Court judiciously considers that the conviction to prison for an offence of the press is not compatible with the freedom of expression of journalists as guaranteed in Article 10 of the Convention unless other fundamental rights are severely affected in respect to the intended purpose, e.g. the public dissemination of a hatred or violence-stirring discourse.

In relation to the discouragement of the punishment, the Court invoked several times the preventive and repressive nature of a number of sanctions classified as administrative or disciplinary under the domestic law, for the purpose of including it in the concept of 'criminal matter'. However, the Court points out to the specific characteristic of discouraging the criminal law in its narrowest sense, to the exclusion of other types of charges, in respect to ensuring the protection of the society's essential values ${ }^{22}$.

In assessing whether the intromission of the criminal law is justified or not in relation to the exercise of some of the rights and freedoms protected by the European Convention, the Court in Strasbourg takes into account in its argumentation not only its objective for the purpose of foreseeing unwanted consequences, but also its function. As far as the freedom of expression is concerned, the Court finds that the criminal punishment of some offences perpetrated in the field of the press are likely to threat the journalist's freedom of expression.

The risk of criminal convictions resides in preventing the press from participating to open debates on questions of public interest ${ }^{23}$. Discouraging such charges is beneficial for the exercise of the journalistic freedom of expression ${ }^{24}$.

However, on the other side, charges inflicted have been extremely severe. The Court recalls that states have the positive obligation to protect the freedom of the press. A punishment system so harsh for investigation journalists may results in their reticence to play

\footnotetext{
17 Points 19-20 in the Resolution no. 1003/1993 of the Parliamentary Assembly of the Council of Europe published in Romania's Official Journal no. 265 of September 20, 1994.

${ }^{18}$ ECHR, December 17, 2004, Cumpănă and Mazăre versus Romania, §115; and also ECHR, September 23, 2004, Feridun Yazar versus Turkey, § 27, 23; ECHR, July 8, 1999, Surek and Ozdemir versus Turkey, §1 63.

${ }^{19}$ ECHR, September 24, 1997, Garyfalou Aebe versus Greece.

${ }^{20}$ ECHR, Pierre-Bloch versus France, October 21, 1997, Recueil 1997-VI, p. 2224, § 53; Malige versus France, 23.09.1998 (http://www.echr.coe.int/, § 35).

${ }^{21}$ Dan Claudiu Dănişor, Principiul retroactivității legii penale sau contravenționale mai favorabile, in Caiete de drept penal no. 4/2009, C.H. Beck, Bucharest, 2009.

${ }^{22}$ Michel Van de Kerchove, Les caracteres et les fonctions de la pein, noeud gordien des relations entre droit pénal et droits de l'homme, in Les droits de l'homme, bouclier ou épée du droit penal?, coordinated by Zves Cartuyvels, Hugues Dumont, Francois Ost, Michel Van de Kerchove, Sébastian Van Drooghenbroeck, Brussels, Facultés Universitaires Saint-Louis, 2007, p. 358.

${ }^{23}$ ECHR, July 8, 1999, Sürek versus Turky.

${ }^{24}$ ECHR, December 17, 2004, Cumpănă and Mazăre versus Romania.
} 
their part, i.e. that of watch dogs for the democracy and proper operation of the democratic rule. In the given context, the Court recorded that claimants have been convicted to prison, irrespectively of whether a reprieve occurred, and adjacently to the automatic interdiction of professional practice as journalist during the execution of the conviction. The Court seems to be highly concerned of the automatic nature of such punishment in relation to the government's obligation to set a legislative framework protecting the freedom of the press. In addition, the same was inflicted upon claimants as complementary unpardoned punishment, which the Court considers to be an excessive charge that can only justify under absolute extraordinary circumstances. The Court thinks such punishment exceeds the government's assessment margin and that Article 10 has been breached.

\section{Place of civil liability in respect to the freedom of expression}

If the repressive regime was for many years considered to ensure the maximum protection of public freedoms, the increased tendency to choose civil liability in respect to freedoms has been noticed of late, a trend also presumed for the European case law in the previous chapter.

In sustaining the absoluteness of the civil liability, the compensations granted have been appreciated as much more important that the relatively modest fines inflicted by judges. This risk was also emphasized by the European Court which recalled the significance of the principle of proportionality ${ }^{25}$.

The French law and practice was never unitary in the way the abuse of the freedom of expression may entitle to compensation considering the existence in the same time of the dispositions of the press law and the article 128 of the Civil Code on the civil liability. First, the specialized practice bet on the fact that the only liability-generating facts are the publication acts specified and punished by the press law of 1881 .

Later on, the French Court of Cassation changed its practice and gradually removed the entire article 1382 of the Civil Code from the area of freedom of expression. From 2005 on, claiming the civil liability is no longer excluded, but it cannot be invoked in order to avoid the relevant disposition of the press law. The Court of Cassation, in a case of 2010, sees the completive function of the civil liability: "the abuse of the freedom of expression and the nonpublic insults upon the regime of the law of July 29, 1881, suppressed by article R621-2 of the Criminal Code, cannot be compensated on the grounds of article 1382 of the Civil Code" 26 .

The French President's suggestion in 2009 of disincriminating obloquy and of transferring the treatment of obloquy to the civil jurisdiction was well received by OSCE and the Council of Europe, although it did not materialize by now as the disincrimination of obloquy is addressed in the Council of Europe's recommendations to Member States in $2010^{27}$.

The increasing number of ECHR convictions also point out to the lack of legislation in certain aspects. It is crucial to recognize what is permitted to say and what the legal consequences are and not necessarily the civil or criminal nature of responsibilities ${ }^{28}$. It has been proved that the civil punishment is most of the times much more efficient than the criminal one and the reduction of the prejudicing person's property is much more painful and better sensed. On the other side, on the opposite part of the victim, "the simple expression of a moral conviction would hardly justify human suffering" 29 .

\footnotetext{
${ }^{25}$ ECHR, June 2008, Avgi Publishing versus Greece, §35; ECHR, February 15, 2005, Steel \& Morris versus UK, § 96.

${ }^{26}$ Cass., 2e civ., February 18, 2010: Communication Commerce electronique, 2010, comm. 38, obs. A. Lepage.

${ }^{27}$ Commission nationale consultative des droits de l'homme, Les droits de l'homme en France. Regards portés par les instances internationales. Rapport 2009-2011, Ed. La documentation Française, Paris, 2011, p. 388.

${ }^{28}$ Loïc Cadiet, foreword for Guillaume Lécuyer, Liberté d'expression et responsabilité. Étude de droit privé. Thèse, Dalloz, Paris, 2006, p. XI.

${ }^{29}$ Herbert Lionel Adolphus Hart, Low, Liberty and Morality, Oxford, Oxford University Press, 1963, pp. 65-66.
} 
Any person, including the journalist, exercising freedom of expression, takes over both obligations and duties. As the Court in Strasbourg states in Stoll versus Switzerland on May 10, 2007, in a universe where the individual faces an increasing flow of information disseminated on both traditional and electronic media ad involving an increasing number of authors, controlling the compliance with the journalistic code of conduct seems more and more important ${ }^{30}$.

The difficulty in qualifying the situations which may entail one's liability is true, whether due to the wrong definition of rules or to their wrong interpretation in the case law, and their materialization into facts is hard despite their precise definition. The higher interest disappears most of the times or gets blurred before the intimidating power of the punishment, which may result in the enforcement of a prudential policy concerning the forms of freedom of expression, leading on its turn to a denial of treating various risky or taboo subjects.

This risk of affecting the supreme interest of the freedom of expression by inflicting disproportionate sanctions is constantly envisaged by the European Court for Human Rights. Accordingly, the Court expresses its concerns about the inhibitory power of disproportionate sanctions on public debate and implicitly on the life of the democratic society through discouragement of open discussions on matters of general interest ${ }^{31}$, of the expression by citizens of their opinions on such issues, for fear of criminal punishment ${ }^{32}$.

Moreover, the Court in Strasbourg appreciates that the seizure of the issues of a journal and the publication of the sanctioning decision in case of publication of articles criticizing the government in widely-spread newspapers may be classified as censure and that such conviction, in case of public debates, is likely to refrain journalist contribution to public debates and to matters concerning community life ${ }^{33}$.

Therefore, the solution given by the Court against such negative consequences is the control of the proportionality of the punishment or of the sanction inflicted for the illicit exercise of the freedom of expression regulated under Article 10, paragraph 2 of the Convention. A first element of such proportionality control is the principle of necessity. Government's involvement must be required to protect the legitimate interest corresponding to an imperative social need. Proportionality is required if the freedom of expression conveys a public interest.

Consequently, governments dispose in principle of an appreciation margin when taking measures limiting the freedom of expression, when enforcing seizure or attachment of a movie ${ }^{34}$ and seizing obscene paintings along with a fine inflicted for the illicit and dangerous nature of the act for the general interest ${ }^{35}$, and a conviction to payment of compensation $^{36}$.

In exercising its power of control, the Court shall under no circumstances have the burden to substitute the domestic jurisdiction, but that of checking the decisions passed by virtue of their power of appreciation in the light of article 10 (Fressoz and Roire versus France [GC], Request no. 29.183/95, paragraph 45, ECHR 1999-1).

In particular, the Court must determine whether the arguments called down by national bodies to justify the intromission are "pertinent and sufficient" and the incriminated measure is "proportionate to intended legitimate purposes" (Chauvy et all versus France, Request no. 64.915/01, paragraph 70, ECHR 2004-VI). The Article 10 in the Convention must convince itself that the national bodies, based on the reasonable appreciation of relevant facts, applied rules consisting to the principles enshrined in Article 10 (see inter lia the

\footnotetext{
${ }^{30}$ ECHR, December 10, 2007, Stoll versus Switzerland, $§ 104$.

${ }^{31}$ ECHR, June 25, 1992, Thorgeir Thorgeirson versus Iceland, $\$ 68$.

${ }^{32}$ ECHR, February 22, 1989, Barford versus Denmark, §29.

${ }^{33}$ ECHR, July 8, 1986, Lingens versus Austria, §44.

${ }^{34}$ ECHR, October 20, 1994, Otto Preminger versus Austria, §55-57.

${ }^{35}$ ECHR, May 24, 1988, Muller versus Switzerland, §68.35-43.

${ }^{36}$ ECHR, July 13, 1995, Tolstoy miloslavsky versus UK, $\$ 48$.
} 
Decision of November 25, 1997 in Zana versus Turkey, Collection of Resolutions and Decisions 1997-VII, page 2.547-2.546, paragraph 51).

In Goodwin against the UK, Resolution of March 27, 1996, the claimant, copy editor at the London newspaper The Engineer received by phone some confidential information on the Tetra company. The copy editor contacts the company by phone to check the facts and to invite the company to make comments in its financial issues and afterwards writes a draft article for editing. Tetra addressed to the court and obtained the obligation of the editorial office not to publish the information received and to reveal the whistle blower for initiation of criminal proceedings. Moreover, the petitioner was convicted to a fine of 5,000 pounds for refusing to obey to the order of submitting personal notes. The European Court considered that the interest of Tetra cannot prevail over the primary interest it has for the freedom of the press, the protection of the newspaper's source had no justification in limiting the right to free expression and Article 10 of the Convention was breached in that case.

The Court must see whether the domestic bodies preserved the balance between the protection of the freedom of expression enshrined in Article 10, on one side, and the right to reputation of the persons in question which is also protected by Article 8 of the Convention as an attribute of private life, on the other side. This last condition may require the adoption of proper positive measures to secure the actual respect for the private life between individuals.

Too broad an interpretation of the freedom of expression would discourage the breach of other rights. Too draconian a protection of a right would not only be dangerous, but also counter-productive since it would discourage the exercise of media's freedom ${ }^{37}$. The Court must clearly and systematically establish the general rules of the balance between the freedom of expression and the legitimate limitations for governments and individuals as well, in a uniform and protective manner for all $^{38}$.

3. The freedom of expression is not an intangible right admitting no restriction. In most cases, it must be reconciled with other imperatives of the sale regulatory value. The case law of the European Court for Human Rights gives us some stable principles however.

In the analysis of the intromission of the public bodies in the exercise of the petitioner's freedom of expression in the light of Article 10 of the Convention, the European Court for Human Rights checks first of all whether such intromission is 'stipulated by law', pursuits a legitimate interest to protection by the state of at least one value (national security, territorial integrity, public safety, defence of public order and prevention of offences, health, ethics, reputation or rights of others, prevention of confidential information disclosure, guarantee of the authority and impartiality of the judiciary power), whether it is 'needed' in a democratic society" 39 and means used to limit the right or the freedom in question are proportionate to the legitimate purpose sought.

First of all, the intromission must be established by law. The concept of 'law' is taken materially and not formally. It is enough for a law to be already endorsed by an accessible and predictable case law.

One of the requirements in relation to the expression 'stipulates by law', to which the European Court agrees, ${ }^{40}$ is the predictability of the concerned measure which allows the citizen to adjust his/her behaviour. He/she must have the reasonable capacity to foresee and the experience shows that no absolute certainty can be reached in relation to the consequences that may arise from a determined act.

37 Irina Moroianu Zlătescu, Un echilibru instabil: Libertatea de exprimare şi interdicția discriminării rasiale, in Revista de drept public, no.1/2001, p. 50.

38 Gérard Cohen-Jonathan, Discrimination raciale et liberté d'expression. A propos de l'arrêt de la Cour EDH dun 23 septembre 1994 “Jersild c. Danemarca”, in Revue universelle des droits de 1'homme", March 15, 1995, vol. 7, no. 1-3, p. 8.

${ }^{39}$ ECHR, Lingeans versus Austria, judgment of July 8, 1996.

${ }^{40}$ ECHR, Tammer versus Estonia, judgment of February 6, 2001. 
Secondly, the intromission must be justified by one of the purposes listed under the second paragraph of Article 10 in the Convention, namely: " The exercise of these freedoms, since it carries with it duties and responsibilities, may be subject to such formalities, conditions, restrictions or penalties as are prescribed by law and are necessary in a democratic society, in the interests of national security, territorial integrity or public safety, for the prevention of disorder or crime, for the protection of health or morals, for the protection of the reputation or rights of others, for preventing the disclosure of information received in confidence, or for maintaining the authority and impartiality of the judiciary".

In respect to the proportionality between the sanction and the intended purpose, as ECHR case law also embraces while acknowledging in principle the jurisdiction of the national courts in establishing the sanctions, the conviction to prison for an offence of the press is not consistent with the principle of journalist' freedom of expression guaranteed by Article 10 of the European Convention but in exceptional circumstances. The regular cases of outrage or affront are not likely to justify the conviction to prison ${ }^{41}$.

The nature and the duration of punishments are also factors to consider in analyzing the proportionality of the intromission ${ }^{42}$. In the opinion of the European Court, the press is protected from too severe a punishment according to the contribution in democratic debates. As far as personal sanctions are concerned, with emphasis on the nature and the duration of punishments, the European Court invites governments according to their dominant position to spare such type of sanctions, although not compatible with Article 10 of the Convention ${ }^{43}$.

The final, highly important principle reviewed by the Court in Strasbourg is whether the intromission is required in a democratic society, i.e. whether it satisfies an imperative social need. We may see prejudice to a right or freedom in all criminal convictions, resulting in their restriction. What makes the difference is that the intromission must be justified by a very strict principle, namely by the principle of 'necessity'.

If the legitimate purpose is to protection the reputation, someone else's rights or other limitations specified in Article 10 of the Convention, according to Court's constant case law, it must be determined whether the challenged intromission corresponds to an imperative social need, is proportionate to the legitimate interest sought and the reasons expressed by national bodies to justify such intromission are relevant and sufficient ${ }^{44}$.

The Court often acknowledged in respect to the seizure of the publication and the interdiction to distribute it that the dispositions of Article 10 of the Convention have been breached and do not classify as measure required in a democratic society ${ }^{45}$.

\section{Conclusions}

In the last period has noted increasingly strong option of choosing civil liability in terms of freedoms, as we have shown that relies and the European jurisprudence.

Any person, including the journalist, exercising freedom of expression, takes over both obligations and duties. Civil or criminal liability, through prohibitions which puts them, marks the border between lawful or unlawful speech. Essential is to know not necessarily the nature of civil or criminal liability, but that which is authorized to say and what are the legal consequences.

It has proved that the civil sanction, most of the time, it is much more effective than criminal sanction, reduction of the heritage in the fault being much more painful and felt better.

\footnotetext{
${ }^{41}$ idem;

${ }^{42}$ ECHR, March 9, 2004, Abdullah Aydin versus Turkey, §34; July 8, 1999, Okcuoglu versus Turkey, §49; May 27, 2003, Skalka versus Poland, $\$ 42$.

${ }^{43}$ ECHR, March 30, 2004, Radio-France versus France, §40, April 23, 1992 Castell versus Spain, $\$ 46$.

${ }^{44}$ ECHR, Constantinescu versus Romania, judgment of June 27, 2000.

${ }^{45}$ ECHR, Çetin et al versus Turkey, Resolution of February 13, 2003; C.S.Y. versus Turkey, ECHR Decision of March 4, 2003; Incal versus Turkey, ECHR judgment of June 9, 1998.
} 


\section{Bibliography}

Cass., 2e civ., 18 februarie 2010: Communication Commerce Electronique, 2010, comm. 38, obs. A. Lepage;

Louriane Josende, Liberté d'expression et démocratie. Réflexion sur un paradoxe, Bruylant, Bruxelles, 2010;

Bouloc Bernard, Vers un déclin de la sanction pénal des atteintes a la dignite?, Recueil Dalloz Sirey, 21/05/2009, n 20 , p. 1373;

D. C. Dănişor, Principiul retroactivității legii penale sau contravenționale mai favorabile, in "Caiete de drept penal" Review, no. 4/2009, C.H. Beck Publishing House, Bucharest, 2009;

Commission nationale consultative des droits de l'homme, Les droits de l'homme en France. Regards portés par les instances interationales. Rapport 2009-2011, La documentation Française, Paris;

ECHR, January 24, 2008, Coutant versus France, in Revue de science criminelle et de droit comparé, 2008, p. 706, obs. Marguénaud;

ECHR, June 2008, Avgi Publishing versus Greece, §35; ECHR, February 15, 2005, Steel \& Morris versus UK, § 96;

Michel Van de Kerchove, Les caracteres et les fonctions de la pein, noeud gordien des relations entre droit pénal et droits de l'homme, in Les droits de l'homme, bouclier ou épée du droit penal?, coordinated by Zves Cartuyvels, Hugues Dumont, Francois Ost, Michel Van de Kerchove, Sébastian Van Drooghenbroeck, Brussels, Facultés Universitaires Saint-Louis, 2007;

D. C. Dănişor, S. Rădulețu, Competența Curții Constituționale. Insulta. Calomnia. Controlul normelor de abrogare, in "Curierul Judiciar" Journal, no. 3/2007, C.H. Beck Publishing House, Bucharest, 2007;

ECHR, December 10, 2007, Stoll versus Switzerland, §104;

Guillaume Lécuyer, Liberté d'expression et responsabilité. Étude de droit privé. Thèse, Dalloz, Paris, 2006;

Loïc Cadiet, Liberté d'expression et responsabilité. Étude de droit privé. Thèse, Dalloz, Paris, 2006,

Gérard Spitéri, Le journaliste et ses pouvoirs, PUF, coll. "Essais", 2004;

ECHR, December 17, 2004, Cumpănă and Mazăre versus Romania, §115; and also ECHR, September 23, 2004, Feridun Yazar versus Turkey, § 27, 23; ECHR, July 8, 1999, Surek and Ozdemir versus Turkey, §1 63;

ECHR, March 30, 2004, Radio-France versus France, §40, April 23, 1992 Castell versus Spain, $\$ 46$;

ECHR, March 9, 2004, Abdullah Aydin versus Turkey, §34; July 8, 1999, Okcuoglu versus Turkey, §49; May 27, 2003, Skalka versus Poland, §42;

ECHR, Çetin et al versus Turkey, Resolution of February 13, 2003; C.S.Y. versus Turkey, ECHR Decision of March 4, 2003; Incal versus Turkey, ECHR judgment of June 9, 1998;

ECHR, March 4, 2003, Yasar Kemel versus Turkey, § 33, (http://www.echr.coe.int/); ECHR, October 22, 2007, Lindon Otchakovsky-Laurrens et al versus France, §59;

Irina Moroianu Zlătescu, Un echilibru instabil: Libertatea de exprimare şi interdicția discriminării rasiale, in "Revista de drept public" Review, no.1/2001;

ECHR, Constantinescu versus Romania, judgment of June 27, 2000; ECHR, October 3, 2000, Du Roy and Malaurie versus France, §36;

Patrice Jourdain, Les principes de la responsabilité civile, Dalloz, Paris, 2000;

ECHR, July 8, 1999, Sürek versus Turky;

Renée Koering-Joulin, Jean- François Seuvic, Droits fondamentaux et droit criminel, AJDA spécial, 1998; 
ECHR, Pierre-Bloch versus France, October 21, 1997, Recueil 1997-VI, p. 2224, § 53;

Malige versus France, 23.09.1998 (http://www.echr.coe.int/, § 35);

ECHR, September 24, 1997, Garyfalou Aebe versus Greece;

Mireille Delmas-Marty, Le paradoxe pénal, în Libertés et droitd fundamentaux, sub direcția M. Delmas-Marty şi Lucas de Leyssac, Paris, Seuil, 1996;

ECHR, July 13, 1995, Tolstoy miloslavsky versus UK, $\S 48$;

ECHR, October 20, 1994, Otto Preminger versus Austria, §55-57;

Points 19-20 in the Resolution no. 1003/1993 of the Parliamentary Assembly of the Council of Europem pblished in Romania's Official Journal no. 265 of September 20, 1994;

ECHR, June 25, 1992, Thorgeir Thorgeirson versus Iceland, §68;

ECHR, February 22, 1989, Barford versus Denmark, §29;

ECHR, May 24, 1988, Muller versus Switzerland, §68.35-43;

Tocquevile, État social et politique de la France avant et depuis 1799, 1838, reedit. Garnier-Flammarion, 1988;

ECHR, July 8, 1986, Lingens versus Austria, §44;

Geneviève Viney, La responsabilité, APD, 1977;

Herbert Lionel Adolphus Hart, Low, Liberty and Morality, Oxford, Oxford University Press, 1963;

Convention for the Protection of Human Rights and Fundamental Freedoms. 